\title{
A COMPARISON OF TWO MINERALOGICAL METHODS APPLIED TO THE DETERMINATION OF THE TERRIGENOUS COMPONENT
}

\begin{abstract}
The terrigenous component of Estonian bedrock was analysed using two methods: method I for the Vendian, Cambrian, Ordovician, and Devonian rocks and method II (express) for the Silurian rocks. This paper compares the results of the two methods applied in parallel for the determination of the terrigenous component of the Silurian carbonate rocks. The most essential differences appear in the amounts of micaceous minerals, opaque heavies, and phosphate minerals. The similarity is the greatest in case of the amounts of allothigenous non-opaque minerals, which can be successfully used for the reconstruction of sedimentation conditions and the determination of stratigraphic boundaries.
\end{abstract}

Investigation of the terrigenous component of sedimentary (resp. carbonate) rocks is of essential help in solving problems of sedimentogenesis and lithogenesis, i. e. problems closely connected with the determination of stratigraphical boundaries and correlations. Examination of allothigenous minerals in the sand-silt fraction under the microscope with the aid of immersion liquids is of special importance. First investigations in this field were started in Estonia by Herbert Viiding about thirty years ago (Вийдинг, 1965). The method was developed on the basis of samples from the Devonian arenaceous sediments. The examined fraction $0.05-0.1 \mathrm{~mm}$ of terrigenous minerals was separated by sieving; next the grains with a diameter smaller than $0.01 \mathrm{~mm}$ were removed by washing. The $0.05-$ $0.1 \mathrm{~mm}$ fraction was separated using bromoform and the light and heavy minerals were determined separately. The most valuable information was received from the allothigenous heavy mineral suite. The method was used for the research of Cambrian and Vendian clastic rocks, and also for the study of the insoluble residue from the Devonian and Ordovician carbonate rocks. The initial weight for a sample of carbonate rock was $1000 \mathrm{~g}$, and it was crushed and dissolved in $10 \%$ acetic acid. Further the procedures with the insoluble residue were carried out as mentioned above. This method of the determination of the mineralogical composition of the insoluble residue is very labour- and time-consuming as the dissolution and separation are long-lasting processes. After washing out the fraction finer than $0.01 \mathrm{~mm}$, the amount of the sample left for sieving is often only $50-100 \mathrm{~g}$ and consists mostly of aggregates and pyrite and $\mathrm{Fe}$ oxides as authigenous heavies. This was the reason why despite of a prolonged period very few Ordovician sections could be investigated using this method.

To increase the labour productivity and the number of studied samples, another method was elaborated for determining the terrigenous component in the insoluble residue of the Silurian carbonate rocks (Юргенсон, 1976). The diameter of the Silurian deepboring core is often only a few centimetres, and the weight of the samples taken for the analysis was 30$50 \mathrm{~g}$. The samples were acidified in $3.5 \%$ hydrochloric acid. The size

* Eesti Teaduste Akadeemia Geoloogia Instituut (Institute of Geology, Estonian Academy of Sciences). EE0105 Tallinn, Estonia pst. 7. Estonia. 

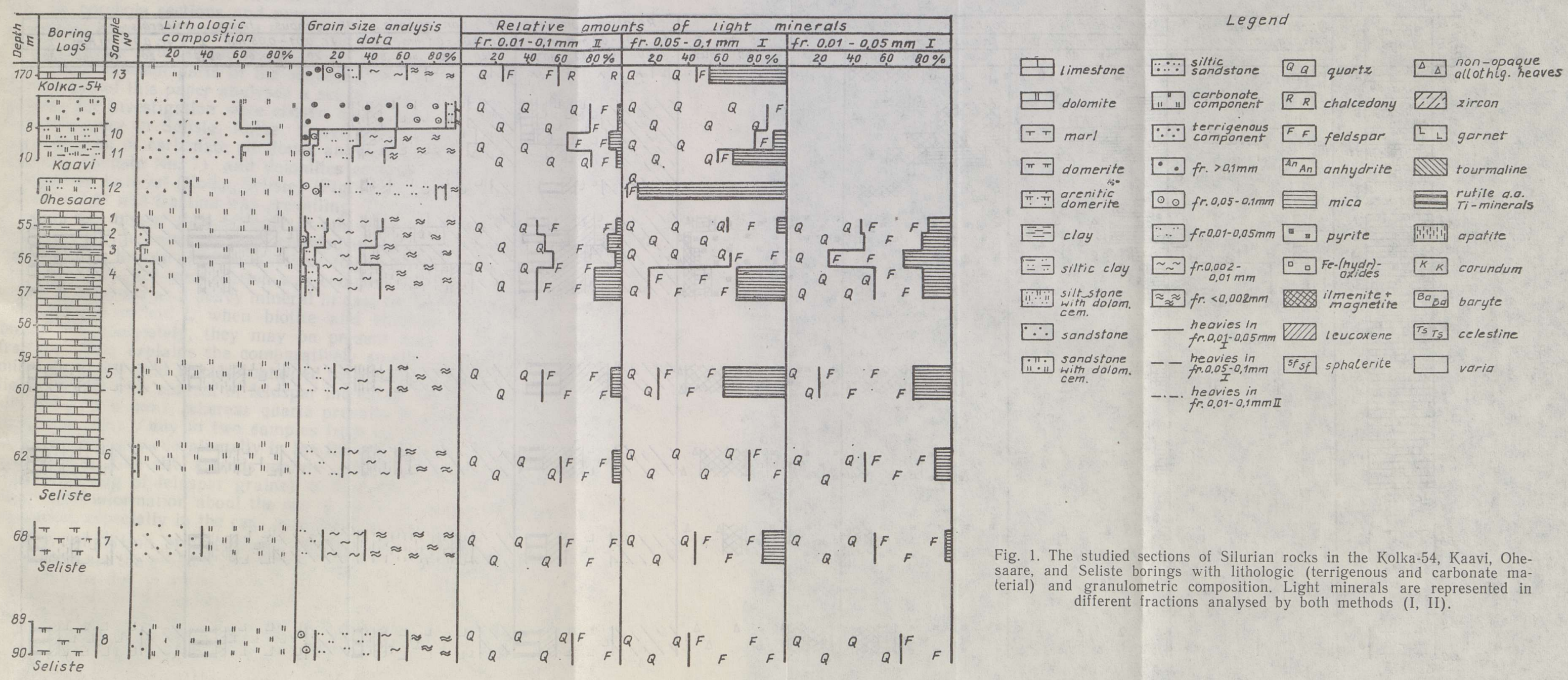


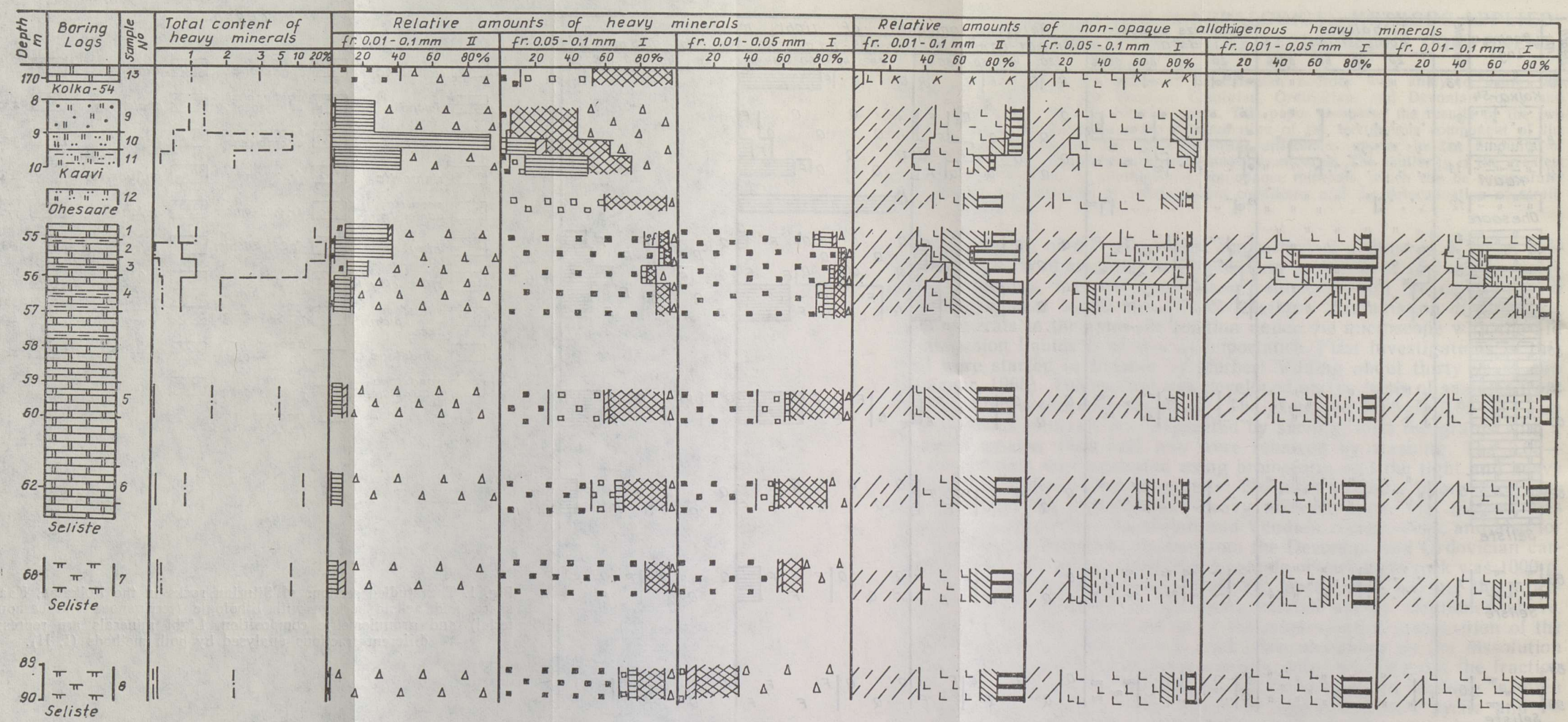

Fig. 2. The content of heavy minerals in the insoluble residue of Silurian carbonate rocks. Comparative data of relative amounts of heavy minerals in different fractions are represented for both methods. See legend in Fig. 1. 
distribution was determined by pipetting and washing; that of the fractions with a diameter bigger than $0.1 \mathrm{~mm}$ by sieving. The terrigenous material in the Silurian carbonate rocks consists mainly of clay and silt fractions and it contains fine sand only in a few cases.

Because of the fineness of the analysed material no separation of the heavy fraction occurred in bromoform. Heavy and light mineral grains were counted in parallel under the microscope. The percentage of light and heavy fractions was calculated from the sum of the grains counted $(500-600)$. The mineral identification was carried out using immersion liquids like in case of the first-mentioned method. About 1300 samples from 52 borehole sections and numerous outcrops of the Silurian carbonate rocks have been analysed by this method (Юргенсон, 1988).

To compare and use the results of the analyses received by methods I and II for different parts of the sequence of bedrock in the Baltic area, the authors of this paper analysed a set of samples by both methods. The sections for investigation were chosen at the level of the Silurian-Devonian boundary in Seliste, Kolka, Kaavi, and Ohesaare boreholes. They are composed of carbonate siltstones and sandstones (Kaavi, Ohesaare), domerite (Seliste No. 7), and dolomites containing different amounts of terrigenous material (Kolka, Seliste) (Fig. 1). In most of the studied samples the $<0.01 \mathrm{~mm}$ fraction was prevailing. The percentage of the sand-silt fraction was bigger than 50 only in one third of the analysed samples. By method I, the minerals were counted in $0.01-0.05 \mathrm{~mm}$ and $0.05-0.1$ $\mathrm{mm}$ fractions and in the two fractions together, while by method II only the whole $0.01-0.1 \mathrm{~mm}$ fraction was counted. Differently from method I, biotite is regarded as a heavy mineral in case method II is applied, whereas in case of method I, when biotite and chlorite do not separate in bromoform completely, they may be present both in light and heavy fractions. This explains the comparatively smaller amount of micaceous minerals in the light fraction obtained by method II (Fig. 1). Among the light minerals, the content of feldspar increases relative to quartz in fine silt $(0.01-0.05 \mathrm{~mm})$, whereas quartz prevails in the coarse silt fraction $(0.05-0.1 \mathrm{~mm})$. Only in two samples from the Seliste core (Nos. 4 and 8) quartz prevails exceptionally in the fine silt fraction. The quartz: feldspar ratio in fine silt depends mainly on the mechanical differentiation (light crushing of feldspar grains) of the sediment, and thus does not yield much information about the source material and conditions of sedimentation, especially in the case of authigenic feldspar.

The comparison of the results got by the two methods shows that differences are the greatest in the total amount of heavy minerals (Fig. 2). This may be due to errors and differences in counting as well as difficulties faced in the determination of opaque minerals in the fine silt fraction. Partly the differences can be explained by the greater solubility of Fe oxides (hematite) in hydrochloride acid. The differences in the results of the analyses seem to decrease with the increasing content of terrigenous material in rocks.

The content of non-opaque allothigenous heavy minerals is somewhat bigger in the fine silt fraction than in the coarse silt fraction (Fig. 2). The difference is the most notable in sample No. 8 from the Seliste borehole. In dolomites and domerites the opaque minerals are concentrated in the coarse silt fraction, while in clastic rocks the situation is the opposite.

In comparing the two methods, attention was focused on non-opaque heavy minerals which are quite diagnostic of the terrigenous material in carbonate rocks. Zircon, garnet, tourmaline, and rutile are the main minerals delivering information since they exist in sufficient quantities in most carbonate rocks. Comparing the results obtained by applying the 


\begin{tabular}{|c|c|c|}
\hline$\frac{\pi}{\pi}$ & วาор!d & 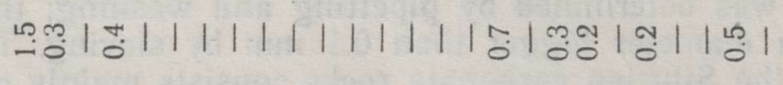 \\
\hline & 竞总 & 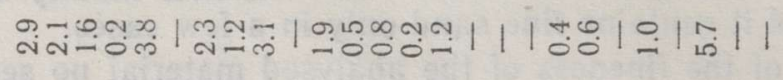 \\
\hline 总 & 로욤 & 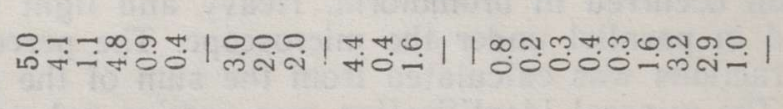 \\
\hline$\overline{\mathrm{E}}$ & 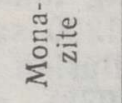 & 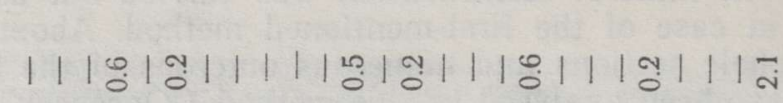 \\
\hline 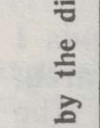 & 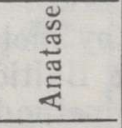 & | 1 | | | | \\
\hline 冚 & 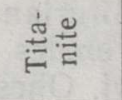 & 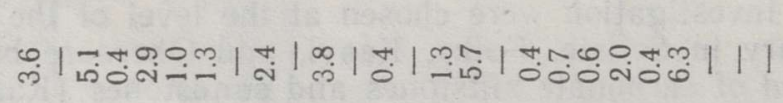 \\
\hline 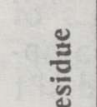 & 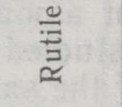 & 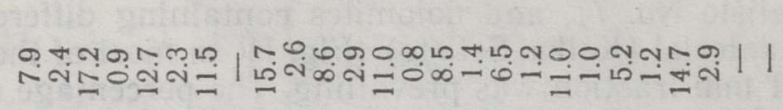 \\
\hline 总 & 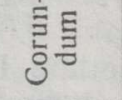 & 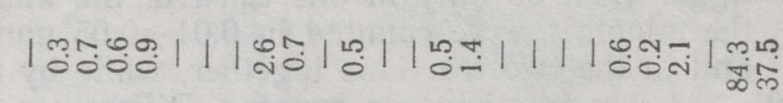 \\
\hline$\overline{0}$ & 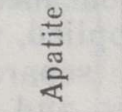 & 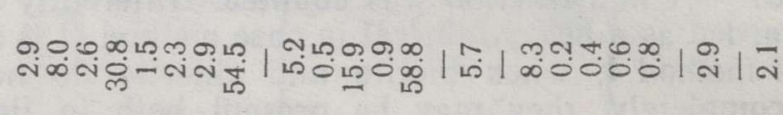 \\
\hline 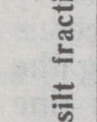 & 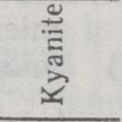 & 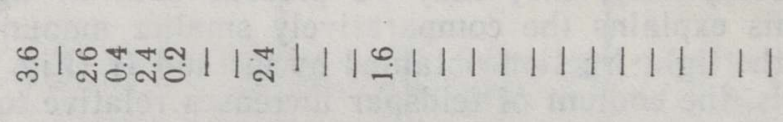 \\
\hline 窇 & 言弯 & 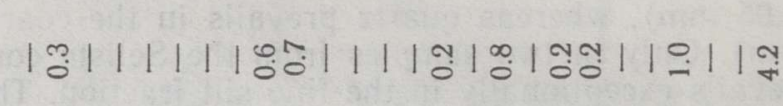 \\
\hline$\stackrel{5}{5}$ & 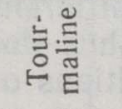 & 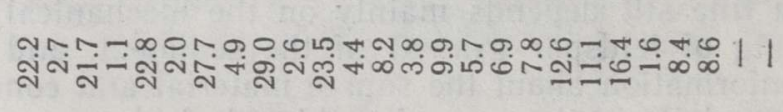 \\
\hline 总 & 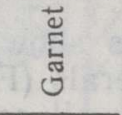 & mo rom \\
\hline 可 & 总 & 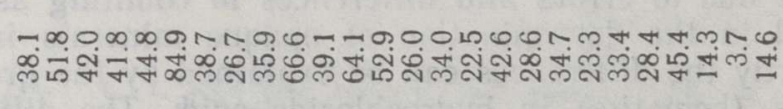 \\
\hline 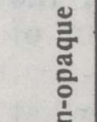 & 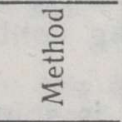 & ニーニーニーニ \\
\hline$\underset{\substack{3 \\
\text { I }}}{3}$ & 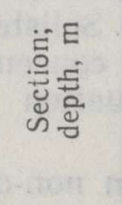 & 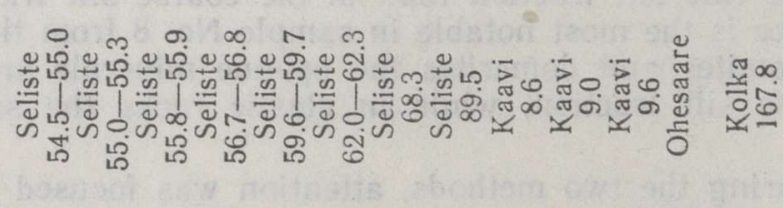 \\
\hline & 菏方 & $-\infty \infty+100 \times \infty 0$ \\
\hline
\end{tabular}


two methods (Table 1, Fig. 2), we must consider that the amount of apatite is modest in the samples dissolved in hydrochloric acid where it is prone to go into solution and to decompose. Certain differences are notable in the content of tourmaline and rutile as well. In the samples treated by method I, rutile concentrates mainly in the $0.01-0.05 \mathrm{~mm}$ fraction (Fig. 2 ), and its total content (fr. $0.01-0.1 \mathrm{~mm}$ ) is considerably smaller than in the corresponding fraction received from the samples by method II. Analogous differences have been established in the content of tourmaline. These differences may be due to the shape and habitus of rutile and tourmaline grains affecting the results of sieving. We cannot measure the "pure" size of a grain by sieving, as the result is affected by both size and shape.

Table 2

Average diameter $(\bar{x})$ and median $(M e)$ of the grains of zircon (120 measurings in $\mathrm{mm}$ in one sample) and garnet $(90)$, and average length $(\bar{y})$ of tourmaline $(80)$ and rutile $(80)$ grains

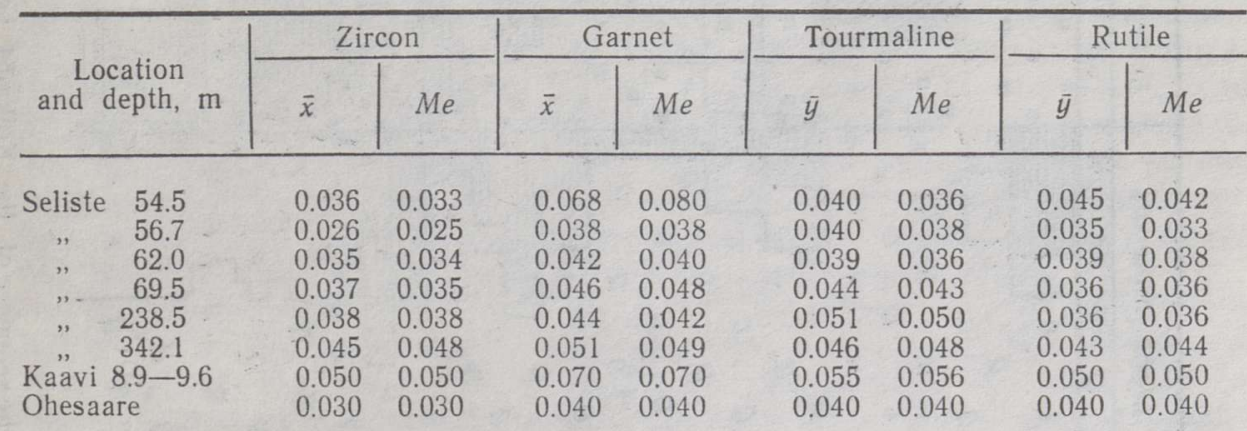

A special measurement was carried out with the four main minerals in samples from different depths under the microscope (Table 2). In the terrigenous material of carbonate rocks, zircon and garnet are mostly well-rounded with an average diameter $0.026-0.050 \mathrm{~mm}$ for zircon and $0.038-0.07 \mathrm{~mm}$ for garnet. Tourmaline and rutile are subrounded preserving still their elongated crystal form. They may behave differently at sieving because the ratio of their length and diameter is about $2-4: 1$, the average length of tourmaline grains being $0.04-0.051 \mathrm{~mm}$ and that of rutile $0,035-0.05 \mathrm{~mm}$. Thus, some grains of rutile and tourmaline may be lost at sieving, and some tourmaline may stay in the light fraction at separation in bromoform.

The similarity between the results of the two methods is greater when the content of the terrigenous component in a sample is higher like in the case of carbonate siltstones of the Kaavi boring (Fig. 2). It is clear that the results received by method II cannot be compared with the results for $0.05-0.1 \mathrm{~mm}$ fraction of the first method. Neither can we compare the contents, but only the tendency of the amounts of minerals toward increasing or decreasing.

Evidently, zircon has a maximum in the Seliste boring at the depth $55.8-55.9 \mathrm{~m}$, while garnet is represented abundantly at the depth of $89.5 \mathrm{~m}$ and in the samples of the Kaavi boring. Rutile is relatively abundant in the Seliste boring at the depth $55.2-55.3 \mathrm{~m}$. The content of corundum has a maximum in the sample of the Kolka-54 boring. The presence of some accessory minerals is significant, too. In the upper part of the Seliste section $(54.5-59.7 \mathrm{~m})$, a notable appearance of kyanite and pyroxene (Table 1) occurs. 


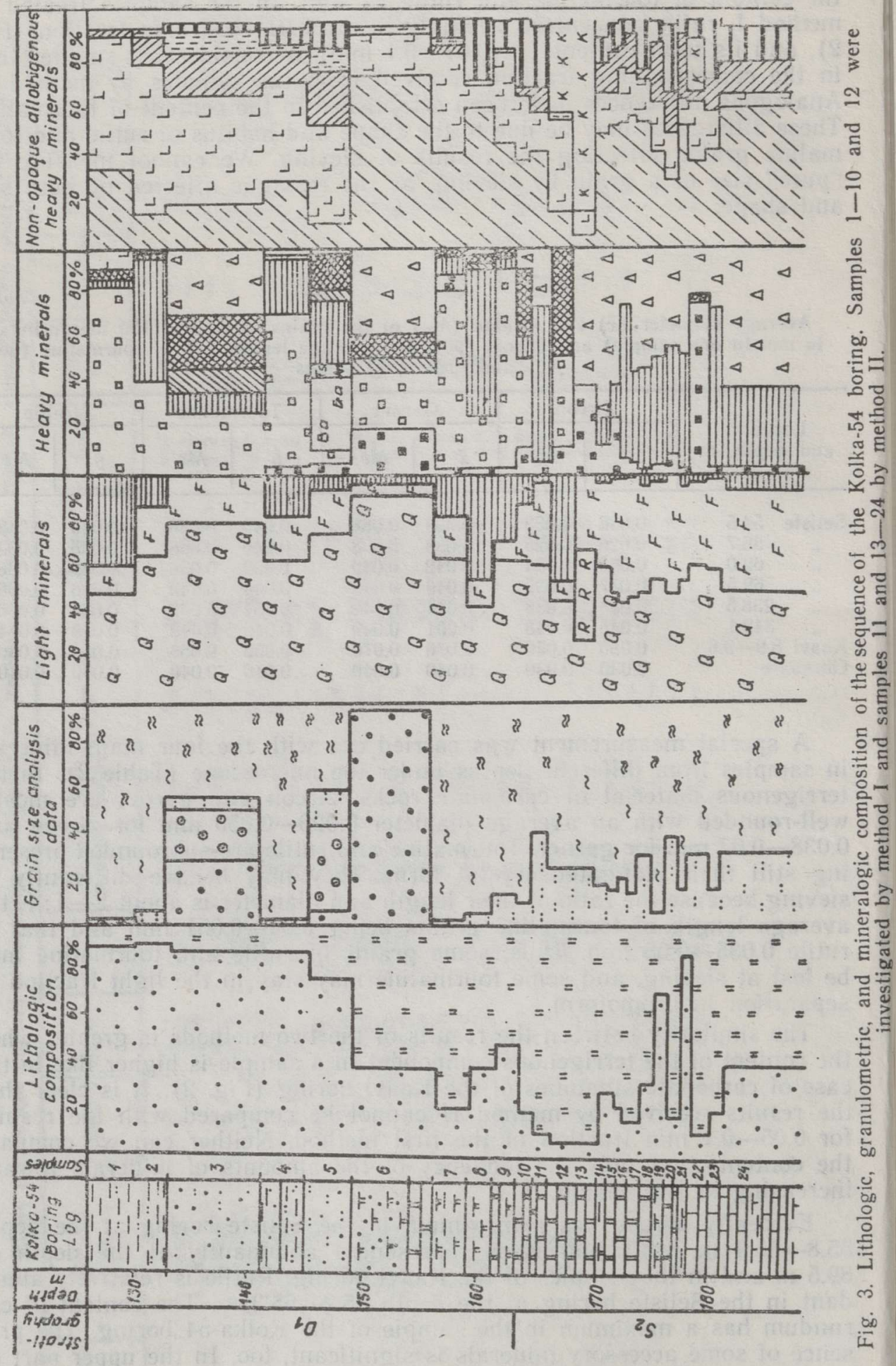


Taking into account the studied material, we can conclude that there is a characteristic relationship between the results of both methods. Considering the above-mentioned differences of the appearance and amount of different minerals (biotite, apatite, tourmaline, opaque minerals), we can successfully use both methods for the reconstruction of the geological circumstances. As an example, we can consider the sequence of the Kolka-54 boring at the Silurian-Devonian boundary, in which the samples of the Devonian beds (except one sample) were investigated mainly by method I (Fig. 3) and the Silurian beds by method II. The results give us an idea of the succession of the geological events at the end of the Caledonian phase of sedimentation. Taking into account the content of non-opaque allothigenous minerals, we can make for instance some provenance determinations. The appearance of corundum in the Upper Silurian beds indicates the continuation of nearshore sedimentation conditions also in the Lower Devonian. The mineralogical character of the beds at the stratigraphic boundary gives evidence of a steady sedimentation process. A notable change in the mineralogical composition indicating a possible break in sedimentation took place at the level between samples 5 and 6 (Fig. 3); in sample 6 the maximum of zircon and quartz content occurs. At this level, relatively coarse and well-weathered material is concentrated. Upwards in the younger sediments, the amount of tourmaline and apatite increases. In the beds immediately overlying those of sample 6 , we can find typical minerals of the sedimentation break, such as baryte, coelestine, and anhydrite. The character of the Lower Devonian sedimentary rocks in the Baltic area indicates a shallow sedimentation basin where the sedimentation process was interrupted by frequent breaks.

We can conclude that both methods may give valuable information about the geological processes that occurred in the past. This investigation suggests that the results obtained are comparable. The choice of the analysis method depends on concrete circumstances. There exist numerous mineralogical analyses which wait for geological interpretation. A preliminary generalization of the mineralogical data of the Baltic bedrock has been given by Viiding and the present authors (Вийдинг, 1976; Юргенсон and Вийдинг, 1982; Вийдинг et al., 1983), but a more detailed treatment of the problem is still needed.

\section{REFERENCES}

Вийдинг Х. 1965. Некоторые методические вопросы литолого-минералогического анализа песчано-алевролитовых пород Прибалтики. - Уч. зап. Тартуск. ун-та, 168. Тр. по геол., III. Тарту, $5-27$.

Bийдине X. 1976. Об интерпретации данных минералогического анализа. - In : Методика и интерпретация результатов минералогических и геохимических исследований. Вильнюс, Мокслас, 53-59.

Вийдине Х. А., Клеесмент А. Э., Конса М. И., Хейнсалу Х. Н., Юргенсон Э. А. 1983. Эволюция минерального состава терригенного компонента осадочного чехла на южном склоне Балтийского щита. - In : Терригенные минералы осадочных пород Прибалтики. Таллинн, 7-22.

Юреенсон Э. 1976. Опыт исследования нерастворимого остатка карбонатных пород. - In : Методика и интерпретация результатов минералогических и геохимических исследований. Вильнюс, Мокслас, $31-36$.

Юргенсон Э. 1988. Осадконакопление в силуре Прибалтики. Таллинн, Валгус.

Юргенсон Э., Вийдинг X. 1982. Особенности кластогенеза в карбонатных породах нижнего палеозоя Северной Прибалтики. - Изв. АН ЭССР. Геол., $\mathbf{3 1}$ 3, 85-93. 


\section{TERRIGEENSE KOMPONENDI MINERAALSE KOOSSEISU MÄARANGUTE SOLLTUVUS METOODIKA VALIKUST}

Terrigeense komponendi määranguid Eesti aluspõhja kivimeis on tehtud kahe metoodika järgi (I, II) ja kõrvutatud tulemusi, mis saadi siluri karbonaatkivimite terrigeense komponendi mineraloogilise koostise paralleelsel määramisel mõlema metoodikaga (tab. 1, joon. 1, 2). Põhierinevused ilmnesid vilkude, raskete opaaksete ja fosfaatsete mineraalide puhul. Lähedasemaid tulemusi andsid allotigeensete raskete läbipaistvate mineraalide määrangud. Kontrollimaks tera kuju mõju granulomeetrilisele koostisele mõõdeti eraldi tsirkooni, granaadi, turmaliini ja rutiili teri mikroskoobis (tab. 2).

Saadud tulemuste kõrvutusest selgub, et mõlemat metoodikat on võimalik edukalt kasutada kivimite settimistingimuste $\mathrm{ja}$ settebasseini arengu rekonstrueerimisel ning stratigraafiliste piiride määramisel. Neid on vōimalik kasutada ka eraldi teatud läbilōike üksikute osade mineraloogilise koostise määramisel, kusjuures säilib muutuste pidevus (joon. 3).

\section{Эрика ЮРГЕНСОН, Анне КЛЕЕСМЕНТ}

\section{СРАВНЕНИЕ ДВУХ МЕТОДИК ОПРЕДЕЛЕНИЯ МИНЕРАЛЬНОГО СОСТАВА ТЕРРИГЕННОГО КОМПОНЕНТА}

Сравнены результаты параллельного определения минерального состава терригенного компонента силурийских карбонатных пород Әстонии двумя методиками (табл. 1 , рис. 1,2$)$. Основные различия выявлены в составе слюд, тяжелых непрозрачных и фосфатных минералов. Более близкие результаты получены для аллотигенных тяжелых прозрачных минералов. Под микроскопом проведены измерения зерен циркона, граната, турмалина и рутила (табл. 2) в целях проверки влияния их формы на гранулометрический состав. Установлено, что обе методики успешно применимы для изучения условий осадконакопления и реконструкции развития осадочного бассейна, а также для определения стратиграфических границ. Применительно к конкретному отрезку одного разреза каждая из методик дает сходную картину изменения минерального состава во времени (рис. 3 ). 